\title{
Cultivating an Institutional Culture That Values Teaching: Developing a Repository of Effective Practices
}

\author{
Lindsay Shaw, Jill Grose, Erika Kustra, Lori Goff, \\ Donna Ellis, and Paola Borin
}

\begin{abstract}
Educational researchers developed an online repository of effective practices contributing to or enhancing the teaching culture at multiple higher education institutions as part of a larger project exploring institutional teaching culture. The repository was designed to be a companion document to the Institutional Teaching Culture Perception Surveys (ITCPS), a resource for administrators, educational developers, and centers for teaching and learning (CTL) striving to cultivate institutional cultures that support the development of teaching and learning. This article outlines the methods for developing this repository, summarizes findings, identifies some of the practices included, and highlights areas for future development.
\end{abstract}

Keywords: teaching culture, effective practices, repository

In higher education, institutional culture reflects the shared values and beliefs (Jacobs, 2016; Tierney \& Lanford, 2018b) that develop from the experiences of an institution's members: students, faculty, staff, and administrators. However, institutional culture is not static but rather shifts slowly and continually, often in response to changing situations, 
demands, priorities, perceptions, and ideas within the institution. Within the larger culture, institutions often have their own complementary and at times competing cultures around research, service, and teaching. In addition, within the broader institutional culture live smaller, but equally dynamic, microcultures of faculties, departments, and centers (Roxå \& Mårtensson, 2015). Despite having a shared goal of fostering student learning, these microcultures may have their own priorities, approaches, and perceptions. With differing roles and differing demands, tensions can arise between these groups (Stensaker, 2018), adding another layer of complexity to the larger institutional culture in higher education.

The current work adopts the institution as the unit of analysis (Riesman \& Jencks, 1962, as cited in Tierney \& Lanford, 2018b, p. 2 ), seeking to identify a holistic view of organizational culture and focusing more specifically on institutional teaching culture, which comprises the embedded patterns, behaviors, shared values, beliefs, and ideologies around teaching (Cox et al., 2011; Kustra et al., 2014). Educational researchers developed an online repository of effective practices identified by faculty and staff as having contributed to or enhanced the teaching culture within their higher education institutions.

\section{Institutional Culture}

To conceptualize institutional culture broadly, Tierney and Lanford (2018a) created a six-item framework that includes institutional mission statement, strategic planning, leadership, information sharing, within-campus socialization, and the campus environment. Their framework focuses on all aspects of an institution and highlights the role of administration in establishing an institutional identity and leveraging their distinguishing features to enact change, with less focus on the specific teaching culture or the contributions of faculty members, staff, and students. 


\section{Institutional Teaching Culture}

The current work focuses on institutional teaching culture more specifically. Institutional teaching culture is important because the extent to which an institution values teaching can influence critical outcomes such as student learning (Cox et al., 2011), engagement (Grayson \& Grayson, 2003), and retention (Berger \& Braxton, 1998), as well as faculty motivation (Feldman \& Paulsen, 1999). More recently, using the Collaborative for Academic Careers in Higher Education (COACHE) surveys, Webber (2019) found that faculty perception of their institutional environment influences their work satisfaction. The highest levels of satisfaction were found in faculty members from primarily baccalaureate colleges, who spend more time teaching, further reinforcing the importance of having an institutional culture that values teaching.

\section{Institutional Teaching Culture Levers}

In 2012, Hénard and Roseveare developed a set of policy levers to improve quality teaching: raising awareness of quality teaching, developing excellent teachers, engaging students, building organization for change and teaching leadership, aligning institutional policies to foster quality teaching, highlighting innovation as a driver for change, and assessing impacts. To adapt this work within a North American context, educational researchers from nine institutions across Canada developed a six-lever framework to identify areas that contribute to an institution's teaching culture. The levers were adapted and clarified through consultations at national and international gatherings of educational developers and faculty and through formal focus groups with faculty, students, and staff (Kustra et al., 2015). The levers are as follows:

1. Institutional Strategic Initiatives and Practices Prioritize Effective Teaching.

2. Assessment of Teaching Is Constructive and Flexible.

3. Effective Teaching Is Implemented. 
4. Infrastructure Exists to Support Teaching.

5. Broad Engagement Occurs Around Teaching.

6. Effective Teaching Is Recognized and Rewarded.

Taken together, these levers have an impact on the culture of teaching within an institution (Shaw et al., 2019). All of the levers align with existing themes in the literature.

For example, starting with Lever 1, administrators can formally lay the groundwork for making teaching and learning an institutional priority (Dennin et al., 2017; Gibbs et al., 2000) by valuing teaching in partnership with research (Hofmeyer et al., 2015). One method of achieving this is encouraging scholarship of teaching and learning (SoTL; Ginsberg \& Bernstein, 2011; Simmons \& Taylor, 2019; Williams et al., 2013). This lever is consistent with most of the framework described by Tierney and Lanford (2018a). Lever 2 suggests teaching evaluations should be designed comprehensively to promote pedagogical development (Ballantyne et al., 2000), which helps build confidence for Lever 3, to enable innovative risk-taking in the classroom (Lock et al., 2018). In Lever 4, a stronger foundation is further established by providing sufficient infrastructure to support teaching, such as centers for teaching and learning (CTLs; Forgie et al., 2018). In Lever 5, an effective teaching culture engages a broader group of people and voices through practices such as Students as Partners (Mercer-Mapstone et al., 2017). And finally, Lever 6 involves acknowledging the value of teaching by recognizing and rewarding quality teachers (Bornais \& Buchholz, 2018). Ultimately, if instructors feel supported, resourced, and rewarded in their teaching, their institution is perceived to value teaching, and they are more likely to teach effectively, which will benefit all students.

\section{Institutional Teaching Culture Perception Surveys}

Using these levers and several sub-items known as indicators, the research team developed the Institutional Teaching Culture Perception Surveys (ITCPS), designed to measure an institution's teaching culture 
at a particular point in time from the perspectives of faculty, students, and the staff who support teaching and learning. For each item in the survey, participants are asked to identify the importance of specific indicators and the extent to which they agree each indicator of a quality teaching culture is evident at their institution. The items vary slightly across the three surveys to reflect the different perspectives of each group (see Table 1). Based on aggregated survey results, institutions can identify levers representing areas of strength and levers that may need further development. To further strengthen levers and enhance their teaching culture, institutions can identify where to focus their attention.

\section{Table 1. Institutional Teaching Culture Perception Survey (ITCPS) Levers and Sample Items}

\begin{tabular}{|c|c|}
\hline Lever & Example survey items within lever \\
\hline $\begin{array}{l}\text { Institutional Strategic Initiatives } \\
\text { and Practices Prioritize } \\
\text { Effective Teaching }\end{array}$ & $\begin{array}{l}\text {...teaching is considered a priority in the primary } \\
\text { institutional strategic plan. } \\
\text {...institution-wide initiatives promote innovative teaching } \\
\text { practices. }\end{array}$ \\
\hline $\begin{array}{l}\text { Assessment of Teaching Is } \\
\text { Constructive and Flexible }\end{array}$ & $\begin{array}{l}\text {...students are invited to provide feedback to their } \\
\text { instructors in addition to end of course evaluations. } \\
\text {...student evaluations of teaching are taken into } \\
\text { consideration in hiring, promotion, and tenure } \\
\text { practices. }\end{array}$ \\
\hline $\begin{array}{l}\text { Effective Teaching Is } \\
\text { Implemented }\end{array}$ & $\begin{array}{l}\text {...instructors adopt a variety of approaches to teaching } \\
\text { and learning. } \\
\text {...instructors tell their students how their course fits into } \\
\text { the curriculum toward a degree. }\end{array}$ \\
\hline $\begin{array}{l}\text { Infrastructure Exists to Support } \\
\text { Teaching }\end{array}$ & $\begin{array}{l}\text {...learning spaces such as classrooms, labs, and/or } \\
\text { studios are designed to support learning (e.g., } \\
\text { movable chairs, sufficient space, appropriate tools, and } \\
\text { technologies). } \\
\text {...instructors have access to adequate materials/supplies } \\
\text { to provide a good learning environment. }\end{array}$ \\
\hline $\begin{array}{l}\text { Broad Engagement Occurs } \\
\text { Around Teaching }\end{array}$ & $\begin{array}{l}\text {...students are involved in activities that foster effective } \\
\text { teaching across the institution (e.g., teaching-related } \\
\text { research, teaching award committees). } \\
\text {...teaching assistants provide effective support for } \\
\text { student learning. }\end{array}$ \\
\hline $\begin{array}{l}\text { Effective Teaching Is Recognized } \\
\text { and Rewarded }\end{array}$ & $\begin{array}{l}\text {...there are institutional rewards for effective teaching } \\
\text { (e.g., financial incentives, teaching awards, etc.). } \\
\text {...teaching accomplishments, contributions, and/or } \\
\text { awards are publicized and/or celebrated. }\end{array}$ \\
\hline
\end{tabular}


Their actions may include consideration of implementing a variety of interventions, possibly including the re-allocation of funding, creation of a new priority in the strategic planning process, or implementation of new initiatives. In a few years, the institution can run the survey again to see if any teaching and learning culture shifts are emerging. The validation of the surveys is an ongoing process, but preliminary evidence has supported the reliability and validity of the surveys (Meadows et al., 2018). The six levers of the ITCPS were initially developed with a strong theoretical background (Hénard \& Roseveare, 2012). Initial studies indicated that each lever had good to excellent internal consistency across all four participant groups (faculty, undergraduate students, graduate students, and staff who support teaching), supporting the reliability of the surveys. Similarly, the validation scales support the convergent validity of the ITCPS levers, particularly for the faculty and student versions (Meadows et al., 2018). As mentioned, institutions may consider implementing interventions related to specific levers, but it is not always clear what interventions may be possible.

\section{Effective Practices Repository}

To complement the research initiative of developing the survey, the team worked on practical support materials to help institutions improve the quality of their teaching culture and respond to their survey results. The online repository of effective practices is one of these supporting documents, which includes examples of successful projects and initiatives that contribute to an institutional culture that values teaching, linked directly to the levers in the ITCPS. Many educators, institutions, and private organizations have developed their own repositories to offer open resources for teachers and learners. Examples include the University of Central Florida Teaching Online Pedagogical Repository (https://topr.online.ucf.edu/), designed to offer resources to faculty and instructional designers on online teaching strategies and the Learning and Teaching Repository in the UK (https://ltr.edu.au/), which offers a collection of teaching materials from 1994 to 2018. 
The purpose of the current repository is fourfold. The first and primary purpose is to identify needs and possible initiatives for organizational change to enhance institutional teaching culture. One practical way this might be achieved is by assisting institutions in responding to their ITCPS results by providing ideas to address teaching culture gaps or to further enhance areas of strength. Second, the repository should be an accessible resource for practitioners, professional associations, and academic administrators who need access to information to make informed decisions. A third purpose is to better understand what institutions are doing to improve teaching and learning and the culture within their institutions. Fourth, by facilitating a knowledge exchange, the repository can promote collaborations across multiple institutions. It is important to note that the repository offers context-specific examples. Teaching culture emerges from the interplay of factors that are unique to each institution, and the interpretation of the ITCPS results and any actions undertaken to respond to them will have the strongest impact when they are generated by people who know that context.

\section{The Canadian Higher Education Institutional Landscape}

Given that the ITCPS has been tested in Canada and the repository practices also stem from Canadian institutions, a brief description of that context may be helpful. Overall, Canadian higher education institutions differ from many of those in the United States in that less variation exists in type, size, and funding. The Canadian higher education system consists of provincially or territorially funded colleges and universities, with few exceptions that operate privately. Colleges typically offer more applied programs, with smaller class sizes and a smaller student population. Humber College (2019) had the largest enrollment in the college system in 2018-2019 with approximately 33,000 full-time students and 23,000 part-time students. Colleges also grant students certificates or diplomas in one or two years as well as three- and four-year degrees in areas of applied studies starting in 2000. Universities, by contrast, are often larger in size, grant three- or four-year undergraduate bachelor's

To Improve the Academy • Vol. 40, No. 1 • Fall 2021 
degrees and graduate degrees. As the largest, the University of Toronto had approximately 91,000 students enrolled in 2018-2019 across their three campuses (University of Toronto, n.d.).

Unlike the Carnegie Classification system in the United States, no formal classification system exists in Canada. However, several universities choose to be included in the Maclean's magazine university rankings that rate universities by reputation and student satisfaction in their individual categories (i.e., medical/doctoral, comprehensive, and primarily undergraduate). Comprehensive universities have established research activities with several programs at the undergraduate and graduate level. Primarily undergraduate universities, however, have few graduate programs and are often smaller in student population. Medical/doctoral universities have similar attributes to those in the comprehensive category but also have medical schools within their institution (Dwyer, 2019).

\section{Developing the Effective Practices Repository}

With the support of an Educational Developers Caucus (EDC) grant from the Society for Teaching and Learning in Higher Education (STLHE), researchers invited others to share their own practices to the repository through national listservs, direct emails to CTL directors, and personal invitations to the researchers' educational networks. The majority of individuals within these networks were educational developers, faculty members, or staff in roles related to teaching and learning (e.g., learning strategist, curriculum specialist, educational technologist). The initial listserv invitations were sent out in November 2018. To probe for further practices, a reminder email was sent through the listservs in March 2019. This reminder email had a more narrowed focus, requesting that participants consider contributing specifically to the three levers that had the fewest number of submissions (Levers 1, 2, and 4). In addition to listserv and word-of-mouth invitations, the research team presented at multiple conferences and 
teaching and learning events. The main purposes of these presentations were to disseminate preliminary practices, seek submissions for new practices, and engage in thoughtful discussions regarding how the repository can better influence the work of educational developers, researchers, faculty, and staff.

To submit a practice, individuals completed an online form in Qualtrics and shared a brief description of the practice, an explanation as to why the practice was effective at improving institutional teaching culture, a list of resources, a contact person, and their institutional affiliation. At the end of the form, participants were asked to select the levers that they felt best aligned with the practice. Participants could skip any question that they did not want to answer and were not limited in the number of practices that they could submit. At the conference presentations, paper versions of the forms were available.

The project was exempted from the project lead's institutional research ethics process as it was deemed by the research ethics board (REB) to be a quality improvement study. Data collection started in November 2018 and stopped in July 2019 when the grant period ended. Prior to being formally submitted into the repository, all practices were reviewed for grammar and applicability. No practices were rejected, but the research team re-categorized or expanded some of the practices into different levers to be consistent with the project's definitions. For instance, under Lever 2 (Assessment of Teaching Is Constructive and Flexible), a participant submitted a student-led program that uses a class representative to gather teaching feedback. The research team re-categorized this practice to also be included in Lever 5 (Broad Engagement Occurs Around Teaching) since students were actively engaged in designing and sustaining the teaching initiative.

\section{Repository Findings}

Between November 2018 and July 2019, a total of 77 distinct practices from 25 institutions across Canada were submitted to the Online 
Repository by educational developers, faculty members, and staff. Using the Maclean's magazine ranking system as reference, the majority of these institutions were universities that have a large student population (over 21,000 students enrolled), are considered comprehensive or medical/doctoral, and are located in central Canada. Although many practices aligned with several of the levers, the majority aligned with Levers 3 (Effective Teaching Is Implemented), 5 (Broad Engagement Occurs Around Teaching), and 6 (Effective Teaching Is Recognized and Rewarded), with the fewest from Levers 2 (Assessment of Teaching Is Constructive and Flexible), 4 (Infrastructure Exists to Support Teaching), and 1 (Institutional Strategic Initiatives and Practices Prioritize Effective Teaching). See Table 2 for the exact number of entries for each lever, along with sample practices.

\section{Sample Repository Entries}

The following section describes sample practices chosen from the repository with explanations on how these practices can help enhance institutional teaching culture. The authors selected these practices because the contributors granted permission to share their examples within the context of this publication. For the purposes of this article, the authors include additional ideas outlining how educational developers and educators alike can play a role in facilitating these practices in their own day-to-day work.

Lever 1: Institutional Strategic Initiatives and Practices Prioritize Effective Teaching

Teaching and Learning Partnership Committees. In response to a dean's request for a dedicated group to work on teaching and learning initiatives, McMaster University created teaching and learning partnership committees in three of its faculties. The committees bring together faculty, educational development staff, and students on a regular basis to discuss teaching and learning issues specific to the 
Table 2. Repository Entries

\begin{tabular}{|c|c|c|}
\hline Lever & $\begin{array}{l}\text { Number of } \\
\text { practices } \\
\text { entered }\end{array}$ & Types of practices \\
\hline $\begin{array}{l}\text { 1. Institutional Strategic } \\
\text { Initiatives and } \\
\text { Practices Prioritize } \\
\text { Effective Teaching }\end{array}$ & 27 & $\begin{array}{l}\text { Learning outcomes framework } \\
\text { Academic plans } \\
\text { Senior teaching positions } \\
\text { Teaching expertise frameworks } \\
\text { Administration podcasts } \\
\text { President's teaching awards } \\
\text { Course outline guides }\end{array}$ \\
\hline $\begin{array}{l}\text { 2. Assessment of } \\
\text { Teaching Is } \\
\text { Constructive and } \\
\text { Flexible }\end{array}$ & 10 & $\begin{array}{l}\text { Peer review } \\
\text { Teaching dossiers } \\
\text { Notice of teaching innovation } \\
\text { Faculty mentoring programs }\end{array}$ \\
\hline $\begin{array}{l}\text { 3. Effective Teaching Is } \\
\text { Implemented }\end{array}$ & 54 & $\begin{array}{l}\text { Program mapping } \\
\text { Curriculum review } \\
\text { Peer review } \\
\text { Training programs } \\
\text { Teaching assistant practicums } \\
\text { Peer-assessment programs } \\
\text { Interprofessional courses } \\
\text { Teaching assistant networks } \\
\text { Educational developer programs } \\
\text { Teaching certificates }\end{array}$ \\
\hline $\begin{array}{l}\text { 4. Infrastructure Exists to } \\
\text { Support Teaching }\end{array}$ & 16 & $\begin{array}{l}\text { Active learning classrooms } \\
\text { Teaching and learning centers } \\
\text { Teaching yurts } \\
\text { Facilitating online learning courses } \\
\text { Experiential learning courses } \\
\text { Universal design for learning } \\
\text { Labyrinth }\end{array}$ \\
\hline $\begin{array}{l}\text { 5. Broad Engagement } \\
\text { Occurs Around } \\
\text { Teaching }\end{array}$ & 43 & $\begin{array}{l}\text { Scholarship institutes } \\
\text { Teaching seminars } \\
\text { Experiential education showcases } \\
\text { Teaching scholars programs } \\
\text { Graduate teaching communities } \\
\text { Teaching and learning fellowship } \\
\text { Teaching and learning partnerships } \\
\text { External academic partners }\end{array}$ \\
\hline $\begin{array}{l}\text { 6. Effective Teaching Is } \\
\text { Recognized and } \\
\text { Rewarded }\end{array}$ & 41 & $\begin{array}{l}\text { Innovation and teaching grants } \\
\text { Learning advancement funds } \\
\text { Teaching large class awards } \\
\text { Teaching assistant awards } \\
\text { Early career teaching awards } \\
\text { Awards for librarians, archivists, and curators } \\
\text { Provincial and national teaching awards }\end{array}$ \\
\hline
\end{tabular}


faculty. This practice enhances the institutional teaching culture by fostering relations among faculty and staff who might not otherwise work together. The committees include students in conversations around teaching and learning, creating a sense of shared responsibility of teaching among all staff, faculty, students, and administrators within the institution. This collaborative model encourages other deans and administrators to get involved in teaching and learning within their units.

Lever 2: Assessment of Teaching Is Constructive and Flexible

Peer Collaboration Network. The University of Windsor's Peer Collaboration Network (PCN) is a reciprocal peer observation initiative. Faculty members meet three times: first, they discuss areas of improvement; second, they observe teaching in the classroom; and third, they provide feedback on the observations. Individual reflections are also embedded within this process to further facilitate the discussions and enhance personal growth. This initiative offers a mechanism outside of student evaluations of teaching for individual faculty to develop their own teaching practices with an overarching goal of enhancing teaching across the entire institution. Although the initiative is open to all instructors, it can be particularly beneficial for new and inexperienced faculty members looking to expand their portfolio, improve their teaching methods, and be more competitive in their tenure and promotion applications (Hubball \& Clarke, 2011). Educational developers can play a key role in housing this initiative within their CTL and being active members within the evaluation process by participating as observers and/or reaffirming the benefits of collegiality, self-reflection, and, of course, pedagogical development (Woodman \& Parappilly, 2019).

Lever 3: Effective Teaching Is Implemented

Instructional Skills Workshop. The Instructional Skills Workshop (ISW) is a multi-day (24-hour) workshop focused on developing teaching 
skills for postsecondary educators (Morrison, 1985) offered at many colleges and universities across Canada. Over the course of the workshop, participants design and conduct three lessons and receive feedback from their peers (Foxe et al., 2017). The participatory workshop encourages self-reflection and pedagogical development while reinforcing the theory and practice of adult learning. The ISW builds a community of practice with new and seasoned faculty members and teaching assistants, offering a mechanism to learn about the culture and value system of the institution. In addition to promoting selfreflection and collegiality, the ISW leaves participants with a pedagogical toolbox of new information to improve their teaching in the classroom (Dawson et al., 2014).

Lever 4: Infrastructure Exists to Support Teaching

Centers for Teaching and Learning. To establish a culture of effective teaching across the university, the University of Windsor first opened the Office of Teaching and Learning (OTL) in 1976 that became the Centre for Teaching in Learning in 2007 (University of Windsor, n.d.). The CTL facilitates partnerships with faculty, staff, and students and offers services related to curriculum design, teaching assessment, high-impact practices, learning outcomes, teaching dossiers, learning management system support, active learning space, grant funding, and mentorship for graduate students and early career faculty. The CTL hosts a range of single workshops to full certificate programs. Ultimately, the CTL is the physical hub that ensures that teaching and learning is supported, funded, and encouraged across the institution.

Lever 5: Broad Engagement Occurs Around Teaching

Leadership in Teaching and Learning Fellowship. With funding from an external donor, the Leadership in Teaching and Learning (LTL) Fellowship program at McMaster University is designed to encourage fulltime instructors to work with other fellows, educational developers, 
and students on a SoTL initiative within one of two streams: evaluating course impact or implementing program change. The program fosters collaboration and mentorship among stakeholders across the institution, creating opportunities for long-term capacity building at the departmental, faculty, and institutional level. Educational developers play a key role in facilitating the development and eventual implementation of the project, supporting opportunities for collegial conversations around teaching and learning and building communities of practice that extend well beyond the fellowship.

Lever 6: Effective Teaching Is Recognized and Rewarded

Learning Innovation and Teaching Enhancement Grants. With funding from the Office of the Associate Vice President, Academic, the University of Waterloo's Centre for Teaching Excellence administers the Learning Innovation and Teaching Enhancement (LITE) Grants to faculty and staff interested in exploring innovative pedagogies to foster deep learning. Past projects have explored curriculum development, experiential learning, assessment practices, language learning, technology, and professional skills development. These grants offer recipients the resources to explore and implement more evidence-based instructional practices. Many of the projects have fostered collaborations across departments and faculties, creating new communities of practice across the institution. Additionally, these researchers have presented at institutional, provincial, national, and international conferences, disseminating findings well beyond the University of Waterloo.

\section{Repository Reflections}

Some of the practices discussed above have been formally assessed for their impact, some are applications of established theory or research evidence, while others represent the wisdom of practice developed in an individual institution or discipline. Wisdom of practice is the 
knowledge drawn on to make professional decisions; it is often tacit and developed in the workplace through experience and non-formal learning (Bamber \& Stefani, 2016). Faculty and educational developers as well as others who work in partnership with CTLs identified many of the practices in the repository. These individuals are change catalysts (Grupp \& Little, 2019; Schroeder, 2011) who are well positioned in their institutions to shift the culture around teaching and learning (Dawson et al., 2010), whether at the micro-level with individual faculty consultations, the meso-level by invoking departmental changes, or the macro-level by inspiring practice within the larger institution or across multiple institutions (Kalu et al., 2018; Schroeder, 2011). It is common practice for CTLs to take the lead on organizing teaching award programs or pulling membership together from across the institution to work on projects to improve pedagogical approaches in the classroom. With this in mind, the research team was not surprised to see that the majority of the submissions fell within these areas of effective teaching (Lever 3), broad engagement (Lever 5), and rewards and recognition (Lever 6).

However, the reason for limited submissions in Levers 1, 2, and 4 seemed less clear. Prior to building the repository, the research team acknowledged that institutional context would play a key role in what is possible to implement (Leibowitz et al., 2015; Zenk, 2017). We expected that some practices would fall under the purview of collective agreements and institutional policies that can be difficult to change or may require specific resources that educational developers or educators alike might not have readily available. For instance, educational developers may recognize the importance of having active learning classrooms with movable chairs and sufficient space that promote student-faculty collaborations (Finkelstein et al., 2016; Jamieson, 2003); however, without financial and physical support from the institution, creating such spaces might not be possible. Ultimately, these macrolevel initiatives present more challenges and in turn more risks for educational developers to spearhead. As described by Grupp and Little (2019), educational developers are constantly navigating the effort 
and load needed to influence institutional change. Some initiatives for Levers 1 and 4 might be infeasible or not be worth the effort, especially if pursuing conflicting priorities risks educational developers losing trust and respect with faculty members and/or academic administrators.

For Lever 2 (Assessment of Teaching Is Constructive and Flexible), the limited number of entries in the repository may be a result of the current conflict-ridden state of student evaluations of teaching in higher education. The lack of robustness and overall governmentality of student evaluations has marked a long history of criticism and mixed findings (Arreola, 2007; Association of American Universities, 2013; Centra, 1998; Centra \& Gaubatz, 2000; Wright et al., 2014), including the recent arbitration at Ryerson University that recommended more comprehensive methods be used to assess teaching (Kaplan, 2018). As such, institutions are facing immediate pressures to think more strategically about the mechanisms used to gather feedback and, subsequently, the decisions made in relation to that feedback. Educational developers play a key role in pedagogical development by engaging in both comprehensive one-on-one consultations and larger institutional initiatives. Yet these voluntary initiatives are happening in concert with mandatory initiatives that are reinforced by institutional policies and procedures, such as student evaluations of teaching. Barrow and Grant (2016) identified the current student evaluation system as just another way to audit teaching within the university, which diminishes the individual work and trust established by educational developers. Overall, expanded systems to assess and provide feedback on teaching may be too new, or still in development, for educational developers to feel confident about sharing the practices as positive contributors to institutional teaching culture.

\section{Repository Limitations}

Despite its usefulness, the repository does have its limitations. The main limitation identified at the conception of the project was 
repository upkeep, as more funding would be required for the ongoing maintenance, update, or expansion of the database. The research team saw enough value in creating the database as a point-in-time resource, and depending on the evolution of the larger ITCPS project, they may seek new funding opportunities to update the repository when needed. The funding amount received also limited how much detail could be shared in the repository. In addition, it was not feasible to assess if, or how, the practices influenced institutional teaching culture. The team had to trust the expertise of the contributor and rely on their wisdom of practice.

\section{Future Research}

Although beyond the scope of the current study, the researchers hope to conduct this assessment work in the future by triangulating the data with the ITCPS or other surveys related to teaching satisfaction (e.g., COACHE). Additionally, in the future, it would be helpful for institutions that have engaged in the ITCPS to repeat the survey and examine changes over time. Similarly, with more funding, specific practices within the repository could be examined for their long-term impact on teaching culture. As mentioned in the beginning of this article, a recent study using the COACHE surveys found that faculty members had higher satisfaction in primarily baccalaureate colleges, where they spend more time teaching and less time conducting research (Webber, 2019). This finding points to the importance of having an institutional culture that values teaching for a positive faculty experience and is worth further exploration.

\section{Implications for Future Practice}

As captured in the missions of educational development professional associations such as the POD Network (https://podnetwork.org/ 
about/) and the EDC of the STLHE, educational developers have long been aware of the value of sharing effective practices and resources among institutions. Through these associations and other networking avenues (e.g., conferences, research partnerships), educational developers have created strong communities of practice from a wide range of disciplines (Harland \& Staniforth, 2008). These communities of practice have created a place to exchange knowledge, master content on specific initiatives, and leverage their power to get administrative buyin (Gehrke \& Kezar, 2017). The repository enables current and future educational developers to build on these strengths, sharing effective practices with their institutions and one another and providing a reference site for colleagues to return to.

How can we leverage the repository to introduce change in our own institutions? Educational developers wear many hats and are constantly entering new situations, which Carew et al. (2008) label "elastic practice." The roles of educational developers as change agents have been discussed for decades and include researchers, assessment resources, critics, translators, coaches, and mentors (Chism, 1998). Increasingly, educational developers are working at the institutional level to effect change. This includes working more directly in partnership with faculty, staff, students, and administrators on initiatives that impact the institution at all levels. Administrators are more likely to adopt a new initiative if it is occurring elsewhere, especially if the institutions have credibility and the initiatives have evidence of success. The repository can also serve as a resource for educational developers to connect and collaborate with colleagues at other institutions who have previously implemented a successful initiative. They can gain advice on unanticipated hurdles and use their credibility to influence administration on the potential success of the initiative (Foote et al., 2016). Repositories, if used in this way, can help reduce barriers for educational developers, such as feelings of imposter syndrome. For example, Rudenga and Gravett (2019) found that $96 \%$ of educational developers in their study experienced imposter syndrome in their day-to-day work. A key contributor to this high prevalence was being considered an institutional 
expert in teaching, even in areas for which they have no formal training. As such, having a resource to rely on the expertise of others is one opportunity for educational developers to overcome this barrier. This approach to decreasing the forces preventing change (barriers) and enhancing the forces supporting changing (effective practices) is consistent with Lewin's (1947) force field analysis model for social change.

As educational developers are increasingly asked to contribute to global initiatives in teaching and learning, particularly for new institutions, what can the repository do to provide concrete examples of how teaching culture is established and maintained? An example includes the EDC Action Group to help the development of new CTLs in universities. This action group evolved into an ongoing formal community of practice in the EDC to support directors of CTLs (https://edc. stlhe.ca/learn/action-groups-cop/). Access to examples such as those contained in the Effective Practice Repository, as well as access to contact information in the institutions, can provide a mechanism for sharing best practices more globally and expanding professional networks. It can also provide a mechanism for more fully understanding and examining the geographical and cultural factors influencing institutional teaching culture in different contexts. Currently, the repository has been used by the nine institutions involved in the research to share practices with upper administration and to identify practices they would like to promote within their own institutions. A guide for interpreting ITCPS results and for using the repository is under development and has been shared with one institution as a pilot.

The repository provides a lens to begin to examine our own practices as educational developers, to review current priorities, and to identify the areas we want to develop. The repository is openly accessible and available to not only educational developers but also individual faculty, senior administrators, and student groups interested in change. Future research will allow evaluation of the impact of methods submitted to the repository as well as deepen our understanding of the array of actions available to support the levers and, ultimately, improve the academy. 


\section{Biographies}

Lindsay Shaw is the Research Coordinator for the Institutional Teaching Culture Project and an Academic Advisor at Brock University. Her research interests include student learning and development, educational policy, and institutional teaching culture. Ishaw2@brocku.ca

Jill Grose is the past Director of the Centre for Pedagogical Innovation at Brock University and is the Co-chair of the International Instructional Skills Workshop (ISW) Advisory Committee. Current interests include international educational development as well as the integration of contemplative and reflective practices into higher education pedagogy. jgrose@brocku.ca

Erika Kustra is the Director of the Centre for Teaching and Learning at the University of Windsor and past Chair of the Canadian Educational Developers Caucus (EDC). She has research interests in and published on scholarly teaching, assessment of centers, learning outcomes, educational leadership, educational development portfolios, conference design, and teaching culture. kustraed@uwindsor.ca

Lori Goff is the Director of the Paul R. MacPherson Institute for Leadership, Innovation and Excellence in Teaching at McMaster University. She has a PhD in Educational Leadership and Policy Studies and is interested in ways that institutional cultures can be shifted through partnerships between faculty, educational development staff, and students. Igoff@mcmaster.ca

Donna Ellis is the Director of the Centre for Teaching Excellence at the University of Waterloo. She is also the President of the Professional and Organizational Development (POD) Network (2020-2021). Her research interests include change management in educational development, organizational development and culture, educational 
innovations, and assessment of teaching and learning centers. donnae@uwaterloo.ca

Paola Borin is a Curriculum Development Consultant at Ryerson University in Toronto, with a background in Curriculum Design and Teacher Education. She advises departments and schools on matters related to curriculum development, revision, and review working through the Office of the Vice Provost Academic to develop strategies to enhance curriculum across the university. Her current research involves analyzing the impact of assessment-related policy changes across multiple universities. borin@ryerson.ca

\section{Acknowledgments}

We would like to thank Sandy Hughes, Peter Wolf, Lynn Taylor, Joseph Beer, Ken N. Meadows, Debra L. Dawson, and Kristin Brown for their contributions to the project. We are also extremely grateful to the faculty members and educational developers from the participating universities for sharing their recommended practices for enhancing institutional teaching culture. This research was supported by the Educational Developers Caucus (EDC) Grant, Social Sciences and Humanities Research Council of Canada (SSHRC) Insight Development Grant, and the Productivity Innovation Fund (PIF), Ontario Ministry of Training, Colleges and Universities.

\section{References}

Arreola, R. A. (2007). Developing a comprehensive faculty evaluation system: A guide to designing, building, and operating large-scale faculty evaluation systems (3rd ed.). Anker.

Association of American Universities. (2013). Framework for systemic change in undergraduate STEM teaching and learning. https://www.aau.edu/ sites/default/files/STEM\%20Scholarship/AAU_Framework.pdf 
Ballantyne, R., Borthwick, J., \& Packer, J. (2000). Beyond student evaluation of teaching: Identifying and addressing academic staff development needs. Assessment and Evaluation in Higher Education, 25(3), 221-236. https:// doi.org/10.1080/713611430

Bamber, V., \& Stefani, L. (2016). Taking up the challenge of evidencing value in educational development: From theory to practice. International Journal for Academic Development, 21(3), 242-254. https://doi.org/10.1080/1360 144X.2015.1100112

Barrow, M., \& Grant, B. M. (2016). Changing mechanisms of governmentality? Academic development in New Zealand and student evaluations of teaching. Higher Education, 72, 589-601. https://doi.org/10.1007/s10734-0159965-8

Berger, J. B., \& Braxton, J. M. (1998). Revising Tinto's interactionalist theory of student departure through theory elaboration: Examining the role of organizational attributes in the persistence process. Research in Higher Education, 39(2), 103-119. https://doi.org/10.1023/A:1018760513769

Bornais, J., \& Buchholz, A. C. (2018). Becoming a more reflective teacher by serving on a university teaching awards committee. Transformative Dialogues: Teaching and Learning Journal, 11(1), 1-10.

Carew, A. L., Lefoe, G., Bell, M., \& Armour, L. (2008). Elastic practice in academic developers. International Journal for Academic Development, 13(1), 51-66. https://doi.org/10.1080/13601440701860250

Centra, J. A. (1998). Development of the Student Instructional Report II. Educational Testing Service.

Centra, J. A., \& Gaubatz, N. B. (2000). Is there gender bias in student evaluations of teaching? The Journal of Higher Education, 71(1), 17-33. https:// doi.org/10.1080/00221546.2000.11780814

Chism, N. V. N. (1998). The role of educational developers in institutional change: From the basement office to the front office. To Improve the Academy, 17, 141-154.

Cox, B. E., Mclntosh, K. L., Reason, R. D., \& Terenzini, P. T. (2011). A culture of teaching: Policy, perception, and practice in higher education. Research in Higher Education, 52(8), 808-829. https://doi.org/10.1007/s11162-011-9223-6

Dawson, D., Borin, P., Meadows, K., Britnell, J., Olsen, K., \& Mclntyre, G. (2014). The impact of the instructional skills workshop on faculty approaches to teaching. Higher Education Quality Council of Ontario. http://www. heqco.ca/SiteCollectionDocuments/Formatted_UWO_Ryerson.pdf

Dawson, D., Mighty, J., \& Britnell, J. (2010). Moving from the periphery to the center of the academy: Faculty developers as leaders of change. New Directions for Teaching and Learning, 2010(122), 69-78. https://doi. org/10.1002/tl.399 
Dennin, M., Schultz, Z. D., Feig, A., Finkelstein, N., Greenhoot, A. F., Hildreth, M., Leibovich, A. K., Martin, J. D., Moldwin, M. B., O'Dowd, D. K., Posey, L. A., Smith, T. L., \& Miller, E. R. (2017). Aligning practice to policies: Changing the culture to recognize and reward teaching at research universities. CBE-Life Sciences Education, 16(4), 1-8. https://doi.org/10.1187/ cbe.17-02-0032

Dwyer, M. (2019, October 3). Maclean's university rankings 2020: Our methodology. Maclean's. https://www.macleans.ca/education/macleans-universityrankings-2020-our-methodology/

Feldman, K. A., \& Paulsen, M. B. (1999). Faculty motivation: The role of a supportive teaching culture. New Directions for Teaching and Learning, 1999(78), 69-78. https://doi.org/10.1002/tl.7807

Finkelstein, A., Ferris, J., Weston, C., \& Winer, L. (2016). Research-informed principles for (re)designing teaching and learning spaces. Journal of Learning Spaces, 5(1), 26-40.

Foote, K., Knaub, A., Henderson, C., Dancy, M., \& Beichner, R. J. (2016). Enabling and challenging factors in institutional reform: The case of SCALE-UP. Physical Review Physics Education Research, 12(1), 1-22. https://doi.org/10.1103/PhysRevPhysEducRes.12.010103

Forgie, S. E., Yonge, O., \& Luth, R. (2018). Centres for teaching and learning across Canada: What's going on? The Canadian Journal for the Scholarship of Teaching and Learning, 9(1). https://doi.org/10.5206/cjsotl-rcacea. 2018.1.9

Foxe, J. P., Frake-Mistak, M., \& Popovic, C. (2017). The instructional skills workshop: A missed opportunity in the UK? Innovations in Education and Teaching International, 54(2), 135-142. https://doi.org/10.1080/14703297 .2016.1257949

Gehrke, S., \& Kezar, A. (2017). The roles of STEM faculty communities of practice in institutional and departmental reform in higher education. American Educational Research Journal, 54(5), 803-833. https://doi.org/10. 3102/0002831217706736

Gibbs, G., Habeshaw, T., \& Yorke, M. (2000). Institutional learning and teaching strategies in English higher education. Higher Education, 40, 351-372. https://doi.org/10.1023/A:1004148310182

Ginsberg, S. M., \& Bernstein, J. L. (2011). Growing the scholarship of teaching and learning through institutional culture change. Journal of the Scholarship of Teaching and Learning, 11(1), 1-12.

Grayson, J. P., \& Grayson, K. (2003, December). Research on retention and attrition. Canada Millennium Scholarship Foundation. https://www.tru. ca/_shared/assets/Grayson_2003_research_on_retention_and_attrition23683.pdf 
Grupp, L. L., \& Little, D. (2019). Finding a fulcrum: Positioning ourselves to leverage change. To Improve the Academy, 38(1), 95-110. https://doi. org/10.1002/tia2.20088

Harland, T., \& Staniforth, D. (2008). A family of strangers: The fragmented nature of academic development. Teaching in Higher Education, 13(6), 669-678. https://doi.org/10.1080/13562510802452392

Hénard, F., \& Roseveare, D. (2012, September). Fostering quality teaching in higher education: Policies and practices. Organization for Economic Cooperation and Development. https://www.oecd.org/education/imhe/ QT\%20policies\%20and\%20practices.pdf

Hofmeyer, A., Sheingold, B. H., Klopper, H. C., \& Warland, J. (2015). Leadership in learning and teaching in higher education: Perspectives of academics in non-formal leadership roles. Contemporary Issues in Education Research, 8(3), 181-192. https://doi.org/10.19030/cier.v8i3.9348

Hubball, H. T., \& Clarke, A. (2011). Scholarly approaches to peer-review of teaching: Emergent frameworks and outcomes in a research-intensive university. Transformative Dialogues Journal, 4(3).

Humber College. (2019, November). Humber College 2018/2019 fact sheet. https://humber.ca/sites/default/files/uploads/documents/humber_fact_ sheet_nov_2019.pdf

Jacobs, A. H. M. (2016). Using a theoretical framework of institutional culture to analyse an institutional strategy document. Education as Change, 20(2), 204-220. http://doi.org/10.17159/1947-9417/2016/944

Jamieson, P. (2003). Designing more effective on-campus teaching and learning spaces: A role for academic developers. International Journal for Academic Development, 8(1-2), 119-133. https://doi.org/10.1080/1360144042000277991

Kalu, F., Dyjur, P., Berenson, C., Grant, K. A., Jeffs, C., Kenny, N., \& Mueller, R. (2018). Seven voices, seven developers, seven one things that guide our practice. To Improve the Academy, 37(1), 111-127. https://doi.org/10. 1002/tia2.20066

Kaplan, W. (2018). In the matter of an interest arbitration. https://www.canlii. org/en/on/onla/doc/2018/2018canlii58446/2018canlii58446.html

Kustra, E., Doci, F., Gillard, K., Dishke Hondzel, C., Goff, L., Gabay, D., Meadows, K., Borin, P., Wolf, P., Ellis, D., Eiliat, H., Grose, J., Dawson, D., \& Hughes, S. (2015). Teaching culture perception: Documenting and transforming institutional teaching cultures. Collected Essays on Learning and Teaching: Transforming Our Learning Experiences, 8, 231-244. https://doi. org/10.22329/celt.v8i0.4267

Kustra, E., Meadows, K. N., Dawson, D., Dishke Hondzel, C., Goff, L., Wolf, P., Ellis, D., Grose, J., Borin, P., \& Hughes, S. (2014). Teaching culture indicators: Enhancing quality teaching. University of Windsor, Ontario, Canada. 
Leibowitz, B., Bozalek, V., van Schalkwyk, S., \& Winberg, C. (2015). Institutional context matters: The professional development of academics as teachers in South African higher education. Higher Education, 69, 315-330. https:// doi.org/10.1007/s10734-014-9777-2

Lewin, K. (1947). Frontiers in group dynamics: Concept, method and reality in social science; social equilibria and social change. Human Relations, 1(1), 5-41. https://doi.org/10.1177/001872674700100103

Lock, J., Kim, B., Koh, K., \& Wilcox, G. (2018). Navigating the tensions of innovative assessment and pedagogy in higher education. The Canadian Journal for the Scholarship of Teaching and Learning, 9(1). https://doi. org/10.5206/cjsotl-rcacea.2018.1.8

Meadows, K. N., Shaw, L., Kustra, E., \& Dawson, D. (2018). Institutional teaching culture perception surveys 2018 preliminary report for the research ethics board. https://qualityteachingculture.files.wordpress.com/2019/01/ itcps-2018-preliminary-report-january-21-2019-3.pdf

Mercer-Mapstone, L., Dvorakova, S. L., Matthews, K. E., Abbot, S., Cheng, B., Felten, P., Knorr, K., Marquis, E., Shammas, R., \& Swaim, K. (2017). A systematic literature review of students as partners in higher education. International Journal for Students as Partners, 1(1), 1-23. https://doi.org/10. 15173/ijsap.v1i1.3119

Morrison, D. (1985). The instructional skills workshop program: An inter-institutional approach. To Improve the Academy, 81, 75-83.

Riesman, D., \& Jencks, C. (1962). The viability of the American college. In N. Sanford (Ed.), The American college: A psychological and social interpretation of the higher learning (pp. 74-192). John Wiley \& Sons. https:// doi.org/10.1037/11181-003

Roxå, T., \& Mårtensson, K. (2015). Microcultures and informal learning: A heuristic guiding analysis of conditions for informal learning in local higher education workplaces. International Journal for Academic Development, 20(2), 193-205. https://doi.org/10.1080/1360144X.2015.1029929

Rudenga, K. J., \& Gravett, E. O. (2019). Imposter phenomenon in educational developers. To Improve the Academy, 38(1), 1-17. https://doi.org/10.1002/ tia2.20092

Schroeder, C. M. (2011). Coming in from the margins: Faculty development's emerging organizational development role in institutional change. Stylus.

Shaw, L., Brown, K., Ellis, D., Wolf, P., Dawson, D., Goff, L., \& Kustra, E. (2019). From perception to practice: A qualitative exploration into institutional teaching culture. Collected Essays on Learning and Teaching, 12, 140-154. https://doi.org/10.22329/celt.v12i0.5397

Simmons, N., \& Taylor, L. K. (2019). Leadership for the scholarship of teaching and learning: Understanding bridges and gaps in practice. The Canadian 
Journal for the Scholarship of Teaching and Learning, 10(1). https://doi. org/10.5206/cjsotl-rcacea.2019.1.7995

Stensaker, B. (2018). Academic development as cultural work: Responding to the organizational complexity of modern higher education institutions. International Journal for Academic Development, 23(4), 274-285. https:// doi.org/10.1080/1360144X.2017.1366322

Tierney, W. G., \& Lanford, M. (2018a). Institutional culture in higher education. In P. N. Teixeira \& J. C. Shin (Eds.), Encyclopedia of international higher education systems and institutions. Springer. https://doi.org/10.1007/ 978-94-017-9553-1

Tierney, W. G., \& Lanford, M. (2018b). Research in higher education, cultural perspectives. In P. N. Teixeira \& J. C. Shin (Eds.), Encyclopedia of international higher education systems and institutions. Springer. https://doi. org/10.1007/978-94-017-9553-1_165-1

University of Toronto. (n.d.). Quick facts. https://www.utoronto.ca/about-u-oft/quick-facts

University of Windsor. (n.d.). CTL timeline. https://ctl.uwindsor.ca/506/ ctl-timeline

Webber, K. L. (2019). Does the environment matter? Faculty satisfaction at 4-year colleges and universities in the USA. Higher Education, 78, 323343. https://doi.org/10.1007/s10734-018-0345-z

Williams, A. L., Verwoord, R., Beery, T. A., Dalton, H., McKinnon, J., Strickland, K., Pace, J., \& Poole, G. (2013). The power of social networks: A model for weaving the scholarship of teaching and learning into institutional culture. Teaching and Learning Inquiry: The ISSOTL Journal, 1(2), 49-62. https:// doi.org/10.20343/teachlearninqu.1.2.49

Woodman, R. J., \& Parappilly, M. B. (2019). The effectiveness of peer review of teaching when performed between early-career academics. Journal of University Teaching \& Learning Practice, 12(1).

Wright, A. W., Hamilton, B., Mighty, J., Scott, J., \& Muirhead, B. (2014). The Ontario universities' teaching evaluation toolkit: A feasibility study. University of Windsor, Windsor, Ontario, Canada.

Zenk, L. R. (2017). Implementing university change: Intersections of academic policy and institutional culture. Journal of Applied Educational and Policy Research, 3(2), 1-9. 